\title{
Penggunaan Media Sosial Instagram dalam Membangun Citra Positif Presiden Joko Widodo pada Pilpres 2019
}

\author{
Dina Fadiyah ${ }^{1^{*}}$, Jimmy Simorangkir ${ }^{2}$ \\ ${ }^{1}$ Jurusan Ilmu Pemerintahan, Universitas 17 Agustus 1045 Jakarta, 14350, Jakarta-Indonesia \\ ${ }^{2}$ Jurusan Ilmu Politik, Universitas 17 Agustus 1045 Jakarta, 14350, Jakarta-Indonesia
}

\begin{tabular}{l}
\hline Info Artikel \\
Dikirim: Mei 20, 2021 \\
Diterima: Jul 17, 2021 \\
Dipublikasi: Jul 31, 2021 \\
\hline
\end{tabular}

Kata Kunci:

Instagram; Kampanye;

Media Sosial; Pilpres;

Presiden;

Koresponden:
Dina Fadiyah

Jurusan Ilmu

Jakarta, 14350 , Jakarta-

Indonesia

Email:

dinafadiyah14@hotmail.com
Universitas 17 Agustus 1945

\begin{abstract}
ABSTRAK
Abstract Social media can be used as a means to gain and maintain fame, namely by presenting a positive image easily and quickly. One of them is Instagram. This study discusses this and specifically aims to research and describe the existence of using Instagram to build a positive image of President Joko Widodo in the 2019 Presidential Election. This research uses a qualitative approach and the results are described descriptively. The focus of this research is to analyze uploads and observe post Widodo's viewpoint during the campaign period 201817 April 2019. Data were collected by interviewing resource persons and also by using documentation techniques. The results of this study indicate that the use of Instagram social media can build a positive image of Joko Widodo as evidenced through his Instagram account by building an impression in front of the audience which includes uploading portraits of his success as a head in the country, among other things, building an idiosyncratic infrastructure as a variety of Indonesian idioms, ideals have as many like on every posting. In addition, there appears to be consistency in building Jokowi's image during the campaign period. This is also supported by Joko Widodo's attitude who is very open-minded and appears offensive in using his personal Instagram for political campaigns. Joko Widodo's use of Instagram in the 2019 presidential election campaign ran easily and effectively in achieving the goal of winning the 2019 presidential election.
\end{abstract}

Sitasi Cantuman:

Abstrak Media sosial dapat digunakan sebagai sarana untuk meraih dan menjaga Dina, F., \& Simorangkir, J. ketenaran, yaitu dengan menampilkan citra positif secara mudah dan cepat. Salah satunya (2021). Penggunaan Media adalah Instagram. Penelitian ini membahas hal tersebut dan secara lebih spesifik bertujuan Sosial Instagram dalam untuk meneliti dan menjabarkan eksistensi penggunaan Instagram guna membangun citra Membangun Citra Positif positif Presiden Joko Widodo pada Pilpres 2019. Penelitian lini menggunakan pendekatan Presiden Joko Widodo pada kualitatif dan hasilnya diuraikan secara deskriptif. Fokus penelitian ini adalah menganalisa Pilpres 2019. Journal of unggahan dan mengamati postingan Instagram milik Joko Widodo pada masa kampanye Political Issues. 3(1); 13-27. hingga pemilihan presiden RI pada 1 Oktober 2018 hingga 17 April 2019. Data https://doi.org/10.33019/jpi.v3i 1.48 dikumpulkan dengan teknik wawancara terhadap nara sumber dan juga dengan menggunakna teknik dokumentasi. Hasil penelitian ini menunjukkan bahwa penggunaan media sosial Instagram dapat membangun citra positif Joko Widodo dibuktikan melalui akun instagram miliknya dengan membangun kesan di hadapan masyarakat imeliputi imengunggah foto-foto keberhasilannya sebagai presiden, misalnya seperti membangun infrastruktur di berbagai tempat di Indonesia, dan mempunyai banyak like pada setiap postingannya. Selain itu tampak adanya konsistensi dalam membangun citra Jokowi selama masa kampanye. Hal tersebut juga didukung sikap Joko Widodo yang sangat terbuka dan tampil ofensif dalam memanfaatkan Instagram pribadinya untuk kampanye politik. Penggunaan Instagram oleh Joko Widodo dalam kampanye Pilpres 2019 berjalan dengan mudah dan efektif dalam mencapai tujuan kemenangan pemilihan presiden 2019.

https://doi.org/10.33019/jpi.v3i 1.48

Lisensi:

\section{Tentang:}

Dina Fadiyah, menyelesaikan studi S2 Politik dan Pemerintahan di Universitas Gadjah Mada pada tahun 2015. Saat ini penulis merupakan dosen tetap di Jurusan Ilmu Pemerintahan Universitas 17 Agustus 1945 Jakarta.

Jimmy Simorangkir, merupakan mahasiswa di Jurusan Ilmu Politik, Universitas 17 Agustus 1945 Jakarta.
Attribution-NonCommercialShareAlike 4.0 International (CC- BY-NC-SA 4.0) 


\section{PENDAHULUAN}

Sosial media merupakan media baru yang memiliki situs yang bisa membuat akun profile sebagai representasi diri kita dan berinteraksi dengan orang lain dan sekaligus media sosial memungkinkan kita berinteraksi dengan banyak orang yang berbeda letak geografisnya namun seperti berada dalam satu lokasi (Dewi \& Janitra, 2018). Kemampuan media sosial yang dilirik semua kalangan ini, kemudian dihadirkan salah satu sarana dalam meraih dan menjaga ketenaran pada suatu pihak dengan aktif berperan dalam media sosial tujuannya untuk menunjukan citra positif dengan mudah dan cepat (Kertamukti, 2015). Media Sosial Intagram yang lebih digunakan sebagai media personal branding dan pembentukan citra positif seseorang dibandingkan untuk berinteraksi dengan orang lain menjadikannya sebagai fenomena baru dimana penggunaan jejaring sosial Instagram tidak lagi dimanfaatkan sebagai media komunikasi dan berbagi karya visual, tetapi lebih mengarah kepada pemanfaatan Instagram sebagai media personal branding yang efektif (Ramadhan, 2019).

Citra diri di dalam media sosial dapat terbentuk ketika kita mengunggah sebuah foto mengenai diri kita di halaman Instagram kita. Instagram adalah bagian dari komunikasi visual yang dapat membangun citra seseorang. Citra merupakan hasil evaluasi dalam diri seseorang berdasarkan persepsi dan pemahaman terhadap gambaran yang telah diolah, diorganisasikan, dan disimpan dalam benak seseorang (Efendi, 2017). Dari penjelasan di atas mengenai citra, dapat berjalan stabil dari waktu ke waktu atau sebaliknya bisa berubah dinamis, diperkaya oleh jutaan pengalaman dan berbagai jalan pikiran asosiatif. Dalam media sosial yang digunakan oleh Joko Widodo, Instagram dengan nama akun @ Jokowi yang telah terverifikasi menjadi media sosial dengan pengikut terbanyak, dimana hal tersebut sejalan dengan fakta yang menerangkan bahwa Instagram merupakan aplikasi media sosial yang paling lama diakses oleh penggunanya dibanding dengan media sosial lainnya (Kertamukti, 2015).

Umumnya kampanye dilakukan dengan pemasangan spanduk, poster, stiker, dan sebagainya. Namun Jokowi memanfaatkan media sosial, sebagai 'senjata' yang saat itu jarang digunakan para calon politik. Sehingga tidak dapat dipungkiri salah satu kekuatan Jokowi dalam berkampanye adalah media sosial. Tak hanya selama masa pemilu, sepanjang masa kepemimpinannya sebagai Presiden RI, Jokowi membuat gebrakan baru dengan memanfaatkan media sosial Instagram sebagai wadah bagi pemerintah untuk menyampaikan informasi dan berkomunikasi dengan masyarakat. Masyarakat berusaha untuk mencari informasi tentang aktivitas kampanye Pilpres 2019 yang dilakukan oleh Jokowi sebagai calon presiden.

Strategi kampanye berbeda yang dilakukan Jokowi tidak hanya pada model face to face communication atau komunikasi tatap muka yang dilakukan, tapi juga penggunaan media kampanye yang dipilih. Media sosial mempunyai peranan untuk Jokowi berkomunikasi dengan publiknya selama masa kampanye berlangsung untuk menyampaikan pesan-pesan politis. Dari sekian media sosial yang digunakan, Instagram yang merupakan satu media yang dijalankan personal oleh Jokowi, hal ini ditunjukkan pula oleh aktivitas Instagram Jokowi yang sangat aktif pada masa kampanye dibandingkan pada masa lainnya. Dibandingkan dengan politisi lainnya di Indonesia, dalam melakukan political branding Jokowi mempunyai urgensi lebih dilihat dari dimensi waktu dimana ia membangun political branding tersebut yakni pada masa kampanye guna mendapatkan vote rakyat. Dalam (Sandra, 2013) dikatakan bahwa partai politik mengukur kesuksesan mereka bukan dalam konsep keuntungan, namun jumlah voting serta kekuasaan yang didapat. Dengan berfokus pada pesan yang disampaikan lewat Instagram akun personal Jokowi, dimana pada akun ini secara personal Jokowi bisa melakukan political branding dengan berfokus pada branding dirinya sendiri.

Penelitian tentang pencitraan seringkali banyak menganalisa pada segi dampak yang dihasilkan. Novelty penelitian ini adalah akan membahas lebih dalam tentang isi konten dari 
Instagram yang dihasilkan oleh Joko Widodo selama kampanye Pilpres 2019 sebagai upaya membangun citra merek. Dimana dalam membangun citra di media sosial sangat besar peluangnya, terutama dalam masa kampanye Pilpres. Instagram sebagai media isosial yang digunakan untuk berkampanye menjadi rujukan resmi masyarakat dalam memantau aktivitas kampanye yang dilakukan capres dan cawapres. Serta akun Instagram Joko Widodo sudah lama dibuat dan memiliki jutaan followers. Sehingga sangat mudah untuk melakukan manajemen kesan melalui akun Instagram pribadi miliknya. Sehingga dengan mudahnya meraup puluhan ribu likes, hal ini akan mendorong pembentukan citra diri yang positif menjelang pilpres 2019 (Ma'aruf, \& Putra 2019). Selain hal yang peneliti paparkan tadi, alasan lain adalah berkaitan dengan kampanye politik yang diantaranya membahas tentang penyampaian pesan atau ide seseorang kepada orang lain, membahas kontak sosial yang dapat dilakukan dengan menggunakan teknologi, dan membahas tentang teknologi media serta peneliti mampu melihat bagaimana respon masyarakat tentang eksistensi penggunaan media sosial instagram dalam membangun citra positif presiden Joko Widodo pada Pilpres 2019.

Tujuan yang ingin dicapai penelitian ini adalah untuk mengetahui dan menjabarkan mengenai Eksistensi Penggunaan Media Sosial Instagram Dalam Membangun Citra Positif Presiden Joko Widodo Pada Pilpres 2019. Hal tersebut sebagai usaha untuk menjawab permasalahan di dalam penelitian ini, yaitu bagimana Penggunaan Media Sosial Instagram Dalam Membangun Citra Positif Presiden Joko Widodo Pada Pilpres 2019, dan Bagaimana proses interaksi komunikasi yang terjadi pada media sosial instagram dalam memenangkan Pilpres 2019.

\section{METODE PENELITIAN}

Metode penelitian ini menggunakan metode penelitian kualitatif berupa metode analisis wacana. Metode analisis wacana adalah metode analisis yang melihat aspek kebahasaan sebagai faktor penting untuk melihat apa yang sedang terjadi di lingkungan sosial masyarakat. Analisis wacana dalam penelitian ini dengan cara menginterpretasi atau menafsirkan teks-teks yang ada, dimana analisis yang terbentuk nantinya kita dipengaruhi dari berbagai faktor, dapat dikatakan bahwa di balik wacana itu terdapat makna dan citra yang diinginkan serta kepentingan yang sedang diperjuangkan (Uchjana, 2003; Satori \& Komariah, 2009)

Data yang digunakan dalam penelitian terbagi menjadi data primer dan data sekunder. Dalam pengumpulan data primer, peneliti menggunakan teknik wawancara (in depth interview) dengan key informan dan beberapa informan. Dan data sekunder berupa data dari dokumen atau literature-literatur yang mendukung data primer dikumpulkan dari buku-buku, yang sesuai dengan penelitian, artikel, kamus, internet dan lain sebagainya, yang membahas tentang penggunaan media sosial instagram dalam membangun citra positif presiden Joko Widodo pada Pilpres 2019.

Data yang diperoleh melalui wawancara selanjutnya dianalisa dengan menggunakan analisis deskritif kualitatif yaitu dideskriptifkan secara menyeluruh. Kemudian untuk analisis wacana, yang mana dalam wawancara berupa teks berita akan dibahas satu persatu. Berdasarkan metode analisis wacana (Fairclough, 2012) analisis data yang akan dilakukan dalam penelitian ini mencakup analisis teks, analisis praktik wacana, dan analisis praktik sosial budaya. Sedangkan untuk menguji keabsahan data yang didapatkan dalam penelitian ini, ada beberapa langkah yang dilakukan oleh peneliti, yaitu perpanjangan masa pengamatan, meningkatkan ketekunan, dan melakukan triangulasi data (Bungin, 2009) 


\section{LANDASAN TEORITIK \\ Kampanye Politik}

Kampanye Politik adalah serentak mengadakan gerakan bisik gerakan dengan jalan menyiarkan kabar angin kampanye. Menurut Rice dan Paisley menyebutkan bahwa kampanye adalah keinginan untuk mempengaruhi kepercayaan dan tingkah laku orang lain dengan daya tarik yang komunikatif. Kampanye politik adalah bentuk komunikasi politik yang dilakukan seseorang atau sekelompok orang atau organisasi politik dalam waktu tertentu untuk memperoleh dukungan politik dari masyarakat (Saputro \& Haryadi 2018). Pengertian kampanye berdasarkan UU Nomor 1 Tahun 2015 tentang Pemilihan Umum Anggota Dewan Perwakilan Rakyat, Dewan Perwakilan Daerah, Dan Dewan Perwakilan Rakyat Daerah pada pasal 1 angka 26 adalah kegiatan Peserta Pemilu untuk meyakinkan para pemilih dengan menawarkan visi, misi, dan program Peserta Pemilu.

Kampanye sebagai serangkaian tindakan komunikasi yang terencana dengan tujuan untuk menciptakan efek tertentu pada sejumlah besar khalayak yang dilakukan secara berkelanjutan pada kurun waktu tertentu (Ardha, 2014; Firmazah, 2007). Beberapa ahli komunikasi mengakui bahwa definisi yang diberikan Rogers dan Storey adalah yang paling popular dan dapat diterima dikalangan ilmuwan komunikasi. Jadi pada dasarnya kampanye merupakan hal lumrah yang sering ditemukan. Bahkan dalam beberapa waktu sering kali ditemukan implementasi dari proses kampanye yang tidak sejalan dengan regulasi yang telah disepakati bersama (Lees-Marshment, 2001).

\section{Media Sosial}

Perkembangan dunia teknologi yang semakin pesat membuat banyak berbagai macam media komunikasi yang membantu mempercepat proses komunikasi dan penyampaian informasi. Dengan menggunakan jaringan internet untuk mengakses kesalah satu situs website, maka setiap orang dapat mengakses informasi dan berita kapanpun dan dimanapun. Internet tidak hanya menyediakan data teks dan gambar, tetapi juga menyediakan data audio dan visual. Kata media di sosial media datang dari medium, atau wadah dimana orang dapat saling berhubungan dan menjalin interaksi sosial. Jadi, sosial media bukan mainstream media layaknya koran, majalah atau televisi.

Sebenarnya sejak zaman dahulu, bahkan era sebelum masehi media sosial sudah ada. Hanya saja, kala itu media sosial mengambil bentuk yang lebih sederhana (Aditya 2013). Pada komputer dan internet, di dalamnya terdapat portal, website (site web), radio online, facebook, twitter, youtube dan masih banyak lagi. Kini, media sosial telah menjadi sangat digital dan mampu mengubah biaya komunikasi yang mahal menjadi terjangkau. Sosial media telah memungkinkan satu manusia berhubungan dengan manusia lain, tanpa batasan ruang dan waktu. Di era digital, sebuah hubungan sosial dapat terjalin dengan sedemikian mudahnya seperti orang pendiam mendadak bisa memiliki hubungan pertemanan dengan orang lain yang jumlahnya banyak.

Seperti yang dikatakan oleh Marshall Mc Luhan bahwa, media adalah perluasan dari eksistensi manusia karena disebut sebagai the extention of man, maka dengan sendirinya media dapat dipandang sebagai perluasan dari kepentingan dan kebutuhan manusia. Dalam lingkup itu manusia mengembangkan diri melalui berbagai cara untuk menentukan tingkat peradaban. Semua fase peradaban memberikan ciri terhadap teknologi yang dihasilkan dan digunakan, dan pada akhirnya media merupakan sistem tentang know-how yang mengarahkan pengetahuan dan mengenalkan seperangkat aturan dan kesempatan baru (Aditya 2013).

\section{Instagram}

Instagram adalah aplikasi yang dapat di gunakan dalam iOS, Android dan Windows 
memudahkan pengguna untuk mengambil foto atau video, mengedit dan mengunggah ke halaman utama Instagram maupun jejaring sosial lainnya (Ramadhan. 2019). Kemudahan dan kecepatannya dalam berbagi foto maupun video menjadi hal yang disukai pengguna, ditambah dengan beberapa filter bergaya retro memberikan cara baru untuk melakukan interaksi melalui foto dan video (Ma'ruf \& Putra 2019).

Pengguna Instagram tidak hanya dapat menerima konten yang disajikan tetapi juga dapat menyukai konten tersebut jika sesuai dengan kemauannya dan memberikan komentar serta mengkritisi konten yang didapatkan. Salah satu keunggulan instagram adalah hasil foto dan video dapat di share ke media sosial lain diantaranya Facebook dan Twitter sehingga konten penyebarannya sangat luas tidak hanya antar pengguna instagram saja. Instagram sangat cocok untuk kegiatan promosi, personal branding, dan pencitraan karena konten yang dihasilkan dapat berupa visual maupun audio visual sehingga dapat dipahami secara jelas dan gamblang agar pengikutnya menjadi lebih ingin tahu informasi lebih lanjut (Fauzia \& Ihsan 2019).

Menurut riset Nielsen Januari 2019 April 2019 menunjukan tingkat pertumbuhan pengguna internet di Indonesia menghabiskan waktu 1,5 jam sehari untuk berinternet. Menurut hasil riset Cuponation jumlah pengguna Instagram di Indonesia mencapai 56 juta penduduk atau 20,97\% dari total populasi di Tanah Air (Cindy \& Sari 2019). Dalam kehidupan sehari-hari, pengungkapan diri atau citra diri seseorang yang berlangsung tidak hanya dalam komunikasi dan interaksi antar manusia, tetapi dapat juga terjadi melalui media perantara, yaitu melalui media sosial. Citra diri seseorang dapat melalui media sosial ini sering terjadi dalam bentuk status, foto/video, komentar dan lain-lainya terkait dengan kejadian yang sedang dialami maupun perasaan yang dimiliki yang dapat dibagikan oleh para pengguna media sosial lainya. Media sosial juga banyak digunakan untuk mengekspresikan perasaan seseorang yang sedang dialami, hal ini merupakan salah satu bentuk citra diri seseorang. Seperti salah satunya Instagram milik Presiden Jokowi yang mendapatkan Jumlah Followers 36 M per-tanggal 9 Oktober 2020.

\section{Political Branding}

Sejak munculnya konsensus diantara partai politik, diferensiasi selama masa kampanye sekarang berdasarkan citra dan personalitas pemimpin. Citra dan personalitas pemimpin dapat dibantu dibentuk oleh proses branding, selain itu branding bahkan bisa membantu kandidat untuk mengubah dan memelihara reputasi serta dukungan (Lees-Marshment, 2009). Branding adalah satu bentuk baru dalam marketing politik dalam reperesentasi psikologikal sebuah produk/organisasi yang lebih mengarah pada simbol dibandingkan kegunaan nilai tangible (Scammell, 2007). Ide dari branding sendiri lebih dari sebuah teori yang bisa diaplikasikan ke kota, negara bahkan politisi dengan memberikan mereka identitas publik.

Political branding adalah cara strategis dari consumer branding untuk membangun cita politik. Menurut Scammell berpendapat bahwa brand yang baik untuk nama perusahaan, kandidat atau produk adalah sama sangat pentingnya karena permintaan konsumen menjadi meningkat dan bisa dengan mudah menjalin relasi dengan taktik moderen untuk memperlakukan kandidat politik sama seperti produk. Dalam tahap dasar, branding politisi dibentuk dari pengertian masyarakat secara subjektif terhadap politisi (Scammell, 2007). Tidak hanya elemen personal kandidat, tapi juga elemen kandidat berupa penampilan seperti gaya rambut, pakaian memberi dampak jelas untuk citra kandidat. Pentingnya branding politik sering disimpulkan dengan argumen-argumen sebagai berikut: branding memasukan sisi emosional, memberikan tanda yang membuat pemilih bisa memilih kandidat dengan lebih mudah. Dengan komunikasi yang lebih interaktif dan membangun, branding bisa mempunyai potensi untuk membangun hubungan dengan masyarakat yang sebelumnya sudah tidak tertarik politik. 
Kategori political branding menurut (Sandra, 2013) terdiri dari personalitas yang meliputi hubungan, orisinalitas, tanggap teknologi, dan nilai personal, kemudian penampilan yang meliputi pakaian, gaya rambut dan gestur tangan, serta pesan Kunci Politik yang terdiri dari harapan, dukungan publik, laporan aktivitas, dan nilai/ideologi politik.

\section{Pencitraan}

Kotler mengemukakan teorinya yang menjelaskan bahwa citra perusahaan adalah respon konsumen pada keseluruhan penawaran yang diberikan perusahaan dan didefinisikan sebagai sejumlah kepercayaan, ide-ide, dan kesan masyarakat pada suatu organisasi (Armstrong, et.al 2014). Citra merupakan kesan, perasaan, gambaran diri publik terhadap perusahaan atau organisasi, kesan yang dengan sengaja diciptakan dari suatu obyek, orang, atau organisasi (Simangunsong, 2004).

Strategi menjadi sangat penting bagi partai politik untuk memenangkan persaingan politik. Schroder menyebut strategi pencitraan sebagai target image (citra yang diinginkan). Setiap organisasi, setiap partai dan setiap kandidat memiliki citra tersendiri di lingkungan dimana ia bergerak. Citra tersebut merupakan gambaran yang ada dalam bayangan masyarakat atau para pemilih tentang organisasi, partai atau kandidat pada periode waktu tertentu. Terkadang gambaran ini masih kosong. Itu artinya, bahwa masyarakat atau pemilih belum mengenal organisasi atau kandidat tersebut sehingga mereka tidak bisa membuat gambaran tentang organisasi atau kandidat yang bersangkutan. Tetapi, di lain pihak, tentu saja, persepsi publik terhadap orang yang terkenal bisa saja tidak menguntungkan. Salah atau benar, elemen-elemen tertentu yang tidak menguntugkan kandidat bisa menjadi bagian yang merugikan akitivitas di masa depan (Schroder 2011).

\section{HASIL PENELITIAN}

\section{Penggunaan Media Sosial Instagram dalam Membangun Citra Positif Presiden Joko Widodo Pada Pilpres 2019}

Citra (image) merupakan bagian terpenting dalam memenangkan sebuah kompetisi, salah satunya dalam pemilihan presiden 2019. Penggunaan media social Instagram dapat membangun citra positif presiden Joko Widodo pada pemilihan presiden 2019. Media sosial merupakan ruang yang bebas bagi para kandidat untuk melakukan kampanye membangun sebuah citranya. Kondisi tersebut mengartikan bahwa lingkup media sosial adalah front stage atau panggung depan. Tiap elit politik yang memiliki media sosial dapat secara bebas mengunggah teks, foto, maupun video yang dianggap dapat meningkatkan dan atau mempertahankan citra mereka.

Berdasarkan observasi dan wawancara yang peneliti lakukan, mengenai citra (image) yang membekas dalam memori para informan dan kemampuan informan untuk mengidentifikasi atau mengenal suatu image, dengan kata lain bagaimana penggunaan media social instagram dalam membangun citra positif Joko Widodo pada pemilihan presiden 2019 di mata masyarakat luas. Instagram sebagai sarana untuk memanajemen citra diri mereka. Joko Widodo membangun kesan melalui akun instagram pribadinya @jokowi dengan baju putih yang dilipat pada tangannya menjadi sebuah identitas tersendiri. Hal tersebut dibuat untuk menekankan pada karya-karya atau kebiasaan beliau berbaur dengan masyarakat supaya sama-sama merakyat. Informasi yang membantu Joko Widodo untuk mengembangkan citra (image) yaitu berdasarkan interaksi dengan pengikut instagramnya. Citra tersebut dapat diketahui melalui wawancara terhadap key informan yang menjadi Tim Kampanye Nasional (TKN) Jokowi-Ma'ruf Amin.

"Saya bekerja sebagai anggota dewan Pengarah tim kampanye nasional (TKN) Jokowi-Ma'ruf Amin, dalam menjaring citra positif Joko Widodo melakukan kegiatan strategi 
digital yaitu kampanye yang membangun citra positif Joko Widodo melalui Instagram berupa photo dan audio visual. Terlihat jelas di instagram banyak orang berkata bahwa jokomi adalah pemimpin yang baik, jujur dan sederhana". (Wawancara tanggal 11 Desember 2020 Pukul 16.30 WIB di kediaman Bapak Dr. Ir. Pramono Anung Wibowo, M.M. J1. H. Ambas No.18. Jakarta Selatan).

Berdasarkan pernyataan dari Bapak Dr. Ir. Pramono Anung Wibowo, M.M. tersebut diketahui bahwa citra Joko Widodo semaksimal mungkin diupayakan memberi kesan terbaik guna meningkatkan citranya. Hal ini didukung dengan postingan dari Dr. Ir. Pramono Anung Wibowo, M.M diakun instagram pribadinya seperti terlihat pada:
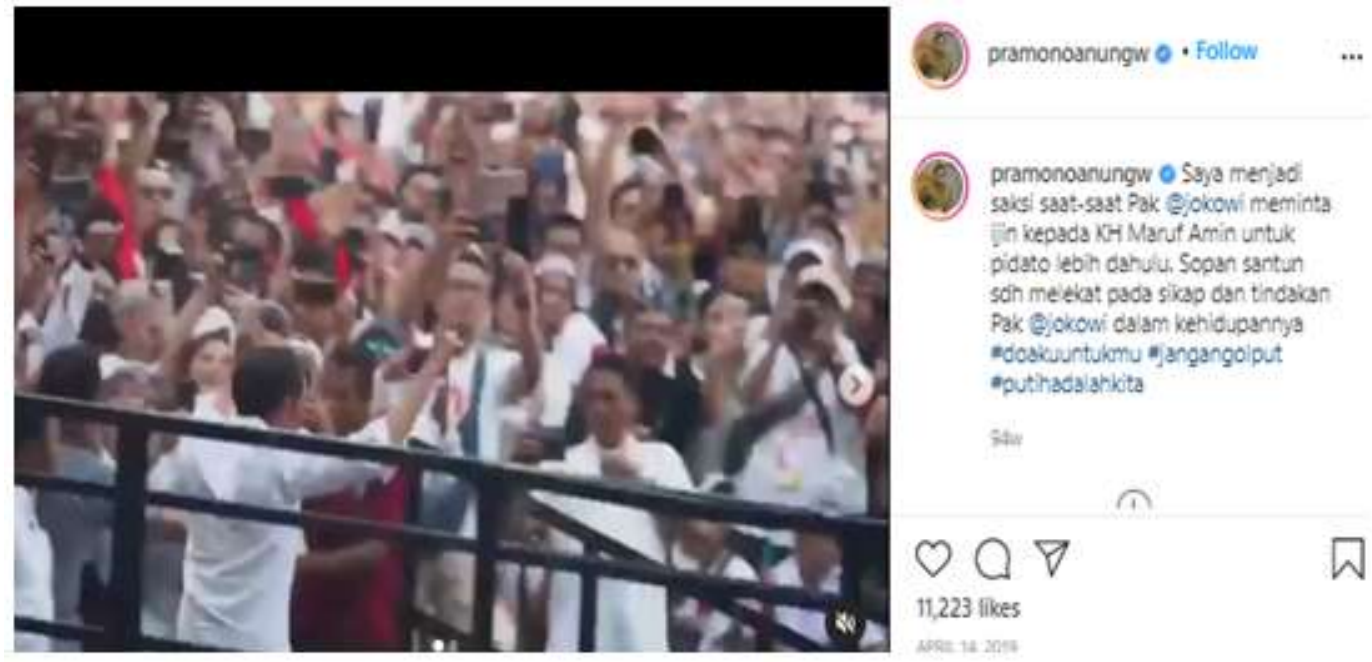

Gambar 1 Sikap dan Tindakan Joko Widodo Saat Ijin Untuk Berpidato Kepada KH. Maruf Amin

Pernyataan Bapak Dr. Ir. Pramono Anung Wibowo, M.M mengenai citra Joko Widodo dibenarkan juga oleh informan lainnya. "Melakukan posting di feed Instagram terkait dengan kampanye Joko Widodo dan mengikuti kampanye Konser Putih Bersatu sebagai bagian dari dukungan terhadap paslon untuk pilpres 2019. Membuktikan bahwa Joko Widodo adalah calon presiden yang mau berbaur dengan semua, merakyat dan untuk rakyat". (Wawancara Addie Muljadi Sumaatmadja tanggal 13 Desember 2020 Pukul 13 Desember 2020 di Pondok Labu, Jakarta Selatan).
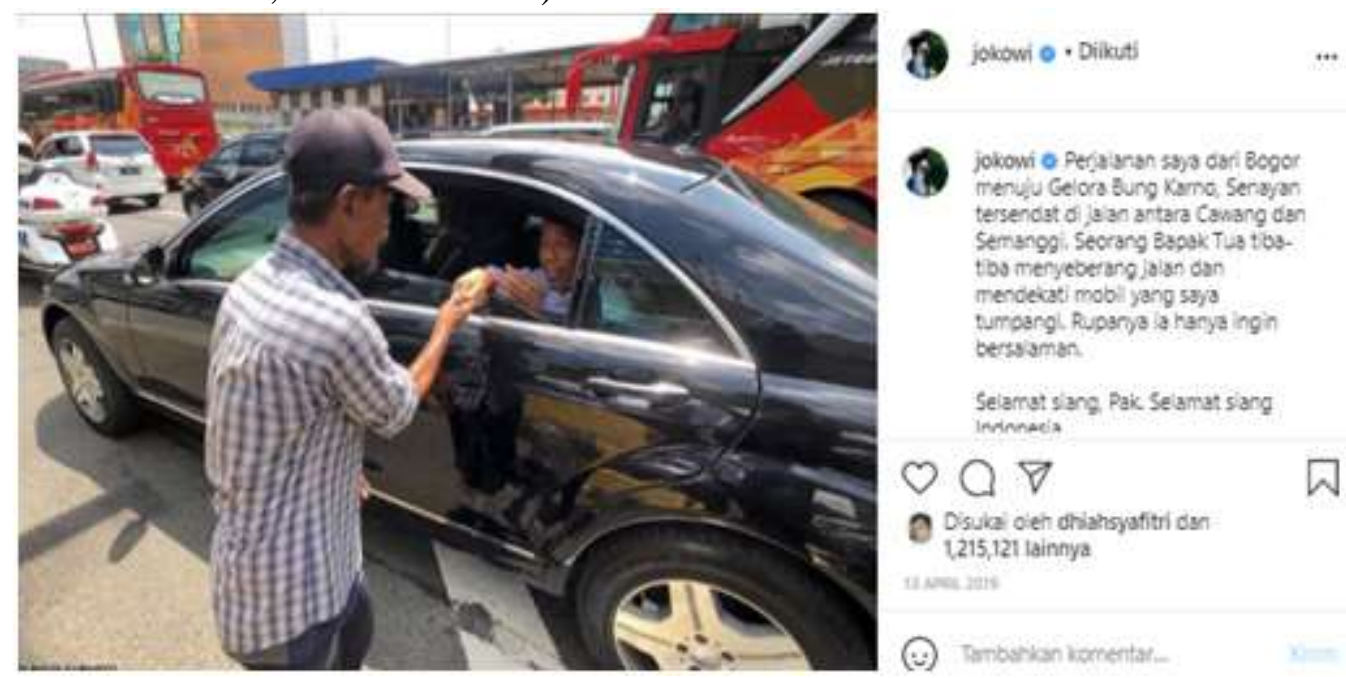

Gambar 2 Joko Widodo Bersalaman dengan Warganya

Terkait pembangunan citra diri capres di media social, Joko Widodo sangat memanfaatkan media sosial untuk membangun citranya. Seolah-olah Joko Widodo sosok capres yang dekat dengan masyarakat, salah satunya dengan mengunggah foto ketika beliau bersalaman dengan masyarakat secara langsung. Efeknya, masyarakat yang melihat 
postingan tersebut memberikan persepsi positif terhadap personal branding Joko Widodo. Salah satu contoh potret Joko Widodo yang menggambarkan bahwa dirinya dekat dengan masyarakat dapat dilihat pada Gambar 3.

Berdasarkan pengamatan dari gambar diatas akun Instagram @jokowi memiliki followers yang cukup banyak. Ketika mengunggah foto atau video, Joko Widodo mendapatkan ratusan ribu likes. Berdasarkan hal tersebut tentunya Joko Widodo lebih mudah dalam membangun citra dirinya melalui Instagram pribadinya. Joko Widodo sudah memiliki jutaan followers dan Instagram miliknya sudah lama dibuat. Informan lain mengatakan bahwa "selain mengikuti kampanye akbar bersama dengan semua pendukung, saya melakukan update di story Instagram saya tentang dukungan saya terhadap beliau, supaya semua orang semakin tergerak dengan paslon ini”. (Wawancara Chacha Frederica tanggal 20 Desember 2020 Pukul 13.00 WIB di Distric 8 SCBD, Jakarta Selatan). Sehingga akun instagram pribadi Joko Widodo dapat membangun citra positif. Upaya tersebut dilakukan agar membentuk citra yang diinginkan dan dapat bersaing dengan calon lainnya.

Media social instagram yang digunakan untuk membangun citra positif, maka Joko Widodo bersama dengan Tim Kampanye nya melakukan kampanye politik dengan tujuan menarik masyarakat untuk mendukungnya dan memilih Joko Widodo dalam pemilihan presiden 2019. Kampanye publik bahkan dianjurkan dilakukan setiap hari (daily campaign). Kampanye yang dilakukan sebagai cerminan dari kultur masyarakat Indonesia yang bersifat paguyuban, suka bergaul, mengobrol, dan satu sama lain. Political branding sebagai cara untuk membangun citra dimata masyarakat. Tidak hanya personal dari kandidat, tapi juga elemen kandidat berupa penampilan dan sikap yang memberikan dampak jelas untuk citra kandidat. Pentingnya kampanye politik memberikan tanda yang membuat pemilih bisa memilih kandidat dengan lebih mudah dan sesuai dengan pilihannya. Dengan komunikasi yang lebih interaktif dan membangun, citra positif mempunyai potensi untuk membangun hubungan dengan masyarakat yang semula tidak tertarik politik menjadi tertarik. Berikut beberapa pendapat mengenai kampanye yang dilakukan Joko Widodo menurut informan dan sumber instagram sebagai pendukung:

"Program yang saya ketahui beliau adalah orang yang merakyat, pastinya programnya juga berbaur dengan rakyat. Pasti banyak yang mendukung beliau". (Wawancara Della pada tanggal 15 Desember 2020 Pukul 18.00 WIB di BSD City Cluster, Tangerang Selatan). Selanjutnya sependapat dengan informan lain. "Programnya masih sama seperti tahun sebelumnya beliau melakukan hal-hal sederhana dan turun ke jalan bersama rakyat". (Wawancara Uswatun pada tanggal 20 Desember 2020 Pukul 16.00 WIB di Jakarta Selatan). Berdasarkan hasil wawancara dari informan, terlihat jelas bahwa persepsi positif Joko Widodo ada, dan tampak pada Gambar 4. 

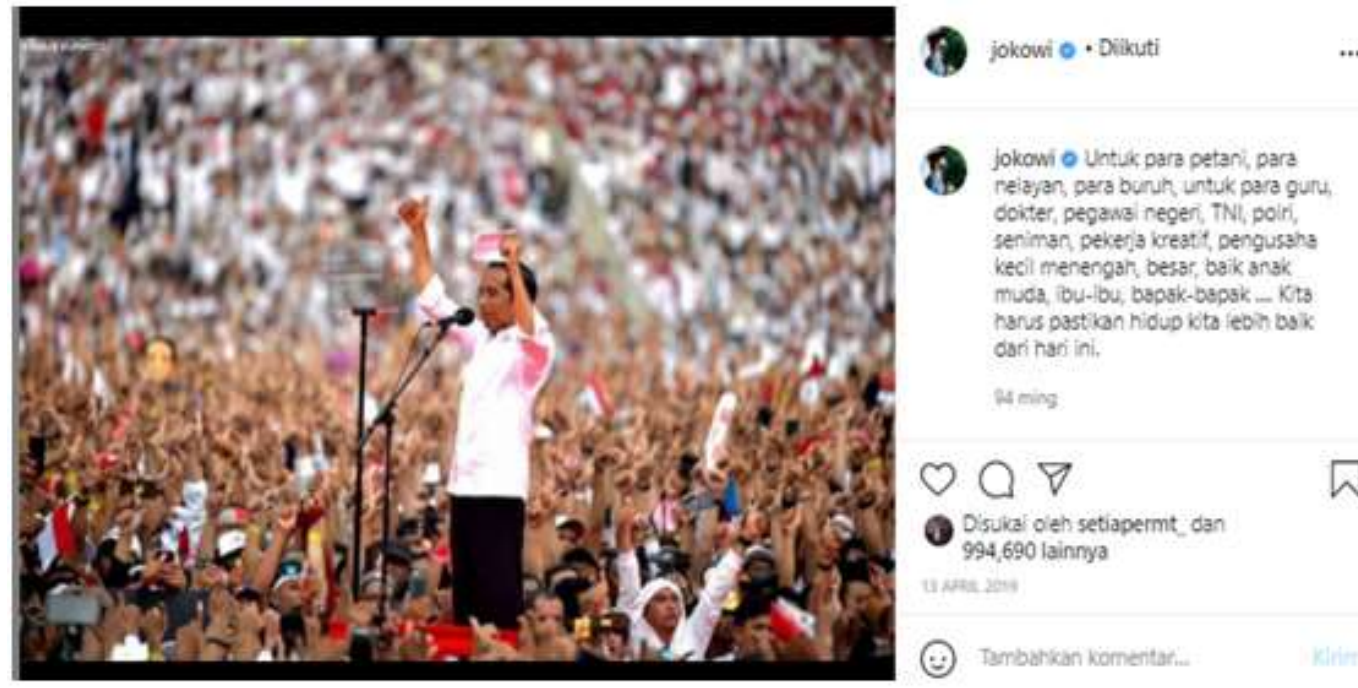

Gambar 3 Kampanye Joko Widodo Mengajak Semua Kalangan Untuk Hidup Lebih Baik

Di Indonesia, penggunaan media social untuk melakukan kampanye politik dapat dengan mudah dilakukan. Media sosial instagram sering digunakan untuk berkampanye sehingga secara tidak langsung dapat menjadi rujukan bagi masyarakat dalam memantau aktivitas capres dan cawapres. Dari beberapa gambar diatas menunjukan bahwa peran aktif dari capres dan para pendukungnya memberikan pengaruh yang signifikan. Sebelumnya kampanye tersebut dilakukan melalui akun instagram pribadi Joko Widodo dalam bentuk post photo dan video, yang kemudian melakukan kampanye ke berbagai daerah dan ditutup dengan kampanye akbar dengan slogan Putihkan GBK. Dari setiap kampanye Joko Widodo selalu memposting aktivitasnya. Hal ini dilakukan agar semua orang dapat melihat kampanye, selain itu masyarakat yang tidak terjangkau dapat melihat euphoria dan pesanpesan yang disampaikan dimanapun berada.

Kampanye yang dilakukan Joko Widodo dan timnya menuai banyak pujian, dimana untuk pertama kalinya kampanye terbesar yang pernah ada. Ini menjadi salah satu khas tersendiri yang berbeda dengan pasangan capres lain-nya. Sesuai dengan pendapat Dewan pengarah Tim Kampanye Nasional (TKN) Joko Widodo-Maruf Amin. "Program yang diusung jokowi dalam kampanye sangatlah berbeda dengan paslon lainnya, dimana jokowi dengan mengusung blusukan bersama rakyat kalangan bawah baik petani, ojek online dan kalangan lainnya". (Wawancara tanggal 11 Desember 2020 Pukul 16.30 WIB di kediaman Bapak Dr. Ir. Pramono Anung Wibowo, M.M. Jl. H. Ambas No.18. Jakarta Selatan).

Kedua pendapat tersebut baik dari informan dan key informan mengatakan bahwa kampanye politik menggunakan media sosial instagram sangat penting. Perkembangan teknologi media social dapat mengubah para capres untuk melakukan "pencitraan" pada diri mereka, Joko Widodo paling banyak memposting tentang peresmian dan perkembangan infrastruktur di negara Indonesia salah satunya saat kampanye di Kota Solo. Selain itu, Joko Widodo juga sering meng-upload video maupun gambar tentang kegiatan blusukan kampanye dan mengajak para petani, nelayan, guru, dan semua kalangan untuk tetap menjalani hidup yang lebih baik. Media sosial instagram sebagai sarana penyaluran komunikasi atau pesan dari Joko Widodo kepada masyarakat atau pendukungnya yang mudah diakses.

Hal di atas sesuai dengan pendapat wawancara dengan informan yang mengatakan bahwa "Media social merupakan media komunikasi yang dengan mudah dapat mengakses semua lapisan, dimana Indonesia terdiri dari sabang sampai merauke yang semuanya tidak dapat dijangkau dengan mudah untuk melakukan kampanye, dengan adanya Instagram dapat menjadi alternative. Tentu saya akan merekomendasikan termasuk kepada followers saya di Instagram". (Wawancara Chacha Frederica tanggal 20 Desember 2020 Pukul 13.00 WIB di Distric 8 SCBD, Jakarta Selatan). Adanya media social instagram dapat membantu 
pencapaian yang mendukung upaya membangun citra positif Joko Widodo dalam Pilpres 2019.

\section{Interaksi Komunikasi yang Terjadi pada Media Sosial Instagram dalam Memenangkan Pilpres 2019}

Interaksi komunikasi pada pemilihan presiden 2019 yaitu menggunakan media social. Jenis media social yang digunakan adalah social networking, jenis ini merupakan yang paling populer di Indonesia seperti instagram. Media sosial sebagai media online, dimana para penggunanya dapat saling terhubung, berkomunikasi, berpartisipasi, berbagi, dan menciptakan konten dari media yang digunakan secara bersama-sama, penggunaan media sosial dalam kampanye politik harus direncanakan sesuai dengan program-program yang telah disusun oleh tokoh politik maupun timsesnya untuk meningkatkan kredibilitas partai atau kredibilitas dari tokoh politik yang bersangkutan. Peluang ini mendorong hampir seluruh tokoh politik untuk membangun citra dirinya di media sosial, apalagi menjelang pemilihan presiden 2019.

Joko Widodo bukan hanya mengunggah foto dan video tentang pembangunan infrastruktur yang berhasil diresmikan dan dinikmati masyarakat, tetapi juga mengunggah foto ketika melakukan interaksi dengan para pengguna media sosial. Di Instagram milik Joko Widodo, ia tidak pernah membalas komentar, baik itu komentar positif maupun negatif. Hal ini menunjukkan bahwa Joko Widodo menciptakan jarak antara warganet dengan dirinya yang berperan sebagai presiden RI dan calon presiden. Seperti pendapat key informan yang mengatakan bahwa "media social merupakan media yang sangat mudah diakses pada zaman sekarang ini, apalagi dengan modal kuota saja kita dapat mengakses informasi terutama kampanye pilpres 2019, tanpa perlu ikut andil dalam orasi dilapangan". (Wawancara tanggal 11 Desember 2020 Pukul 16.30 WIB di kediaman Bapak Dr. Ir. Pramono Anung Wibowo, M.M. Jl. H. Ambas No.18. Jakarta Selatan).
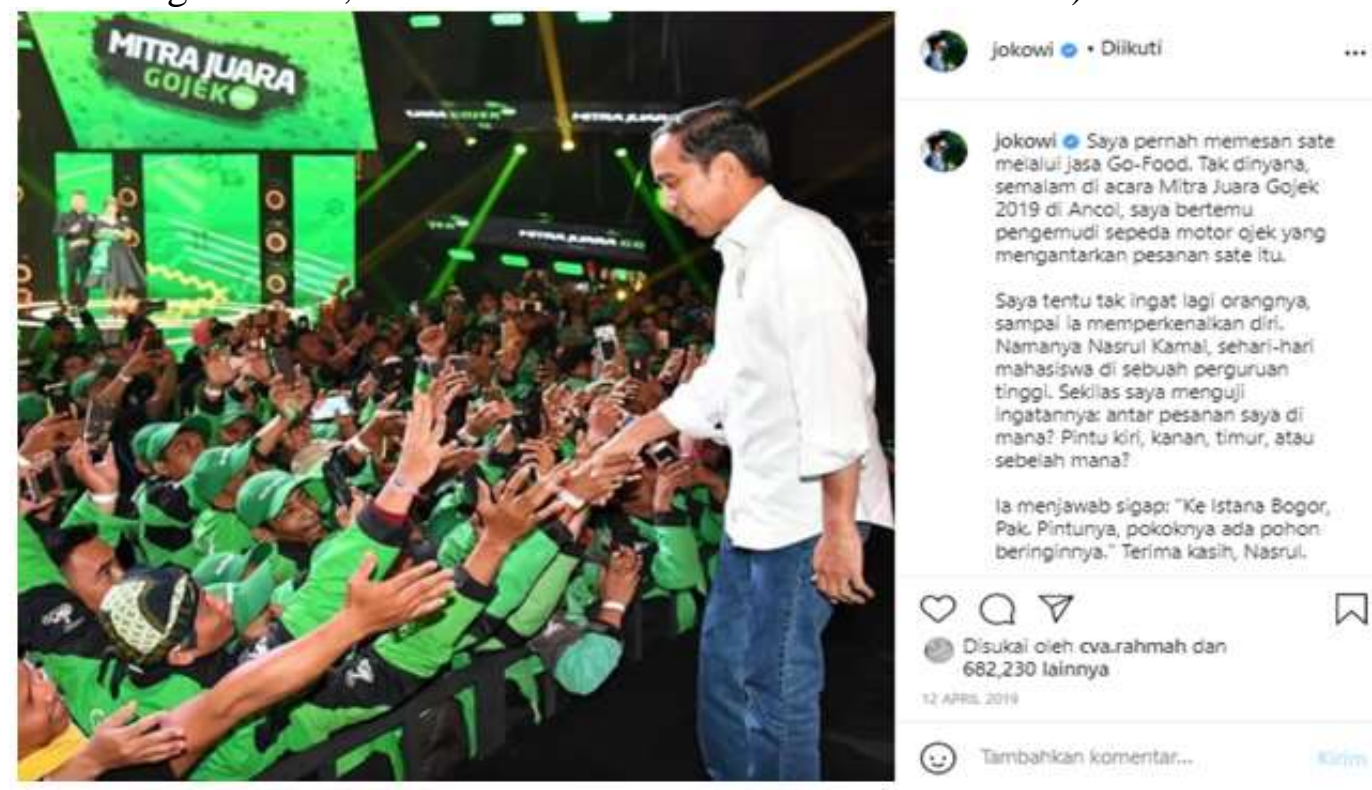

Gambar 4 Joko Widodo Berinteraksi dengan Driver Gojek

Dari beragam post tersebut, tak jarang Joko Widodo mengunggah potretnya yang sedang berinteraksi dengan masyarakat, dan menjabat tangan untuk bersalaman serta mendengarkan apa yang mereka katakan (Gambar 5). Di Instagram miliknya, Joko Widodo tidak hanya memainkan peran sebagai pemimpin sebuah negara dan calon presiden namun memberikan arahan yang sesuai untuk peduli terhadap lingkungan. 
Penggunaan media social dalam membangun citra positif Joko Widodo, dimana langkah utama adalah membangun citra seperti yang telah dijelaskan sebelumnya diatas, kemudian melakukan kampanye politik untuk mendukung citra dan membuat kesan yang baik di mata masyarakat luas. Terakhir adalah kesesuaian, suatu citra dapat dikatakan sesuai ketika terbentuknya image yang dapat bertahan lama, terutama bertahan sampai masa pemilihan presiden 2019 berlangsung.

\section{PEMBAHASAN}

Perkembangan teknologi mengubah para calon presiden untuk melakukan pencitraan pada diri mereka. Pada pemilihan presiden tahun 2019 media social digunakan oleh tokoh politik dalam membangun citranya. Pada tahun 2019, Joko Widodo melihat peluang untuk memanfaatkan media sosial yang digemari oleh anak-anak muda, salah satunya Instagram. Dilihat dari jumlah postingan pada akun instagram pribadi Joko Widodo selama kampanye terdapat 502 postingan yang menggambarkan beberapa keberhasilan Joko Widodo saat menjadi Presiden RI, melakukan kampanye ke berbagai daerah, bertemu dengan rakyat kecil langsung dan memperlihatkan kedekatannya dengan keluarganya. Hal ini yang menjadikan media sosial khususnya instagram dapat mempengaruhi persepsi atau penilaian terhadap calon presidennya. Dengan melihat secara visual baik melalui photo dan video dapat menarik orang untuk simpati dan mendukung. Keunggulan dari Instagram adalah dapat dengan cepat memberikan informasi dan mempengaruhi viewers, dimana Instagram digandrungi oleh anakanak muda, salah satunya keunggulan audiovisual dan jumlah karakter yang tidak terbatas dan bebas untuk memberikan like, komentar dan bahkan untuk merepost supaya orang lain dapat membaca atau mengetahui informasi (news breaking).

Dengan menggunakan analisis wacana didalam penelitian ini, dapat menafsirkan teksteks yang ada. Dimana analisis yang terbentuk nantinya dapat dikatakan bahwa di balik wacana yang dihadirkan terdapat makna dan citra yang diinginkan serta kepentingan yang sedang diperjuangkan. Analisis wacana hasil wawancara yang berupa teks berita akan dibahas dari akun resmi Instagram Joko Widodo dan dari akun instagram para pendukungnya. Dari hasil penelitian diatas bahwa 11 foto yang ditampilkan sebelumnya menunjukkan bahwa Jokowi memiliki berbagai citra yang dapat mempengaruhi masyarakat luas salah satunya yang paling ditonjolkan sesuai gambar diatas yaitu perilaku berbaur Joko Widodo dengan masyarakat bawah, murid pesantren dan lain-lain yang menjadikan bahwa orang No.1 di Indonesia dapat dekat dan merakyat dengan rakyatnya. Selain itu menggunakan Instagram sebagai panggung depannya dengan membangun citra positifnya dengan menggunakan keberhasilannya selama menjabat menjadi presiden seperti membangun infrastruktur, mendengarkan aspirasi rakyatnya terutama untuk kelas bawah dan memperlihatkan hubungan harmonis bersama keluarganya. Salah satu foto yang diunggah di akun Instagramnya menggambarkan keharmonisan Joko Widodo dengan Istrinya ketika saat berkampanye. Hal ini membuat rasa simpati masyarakat beranggapan beliau dekat dengan keluarganya mencerminkan hubungan baik dengan rakyatnya. Citra baik tersebut merupakan gambaran yang ada didalam bayangan masyarakat tentang Jokowi.

Dari beberapa foto yang diposting dapat ditelaah adalah bahwa satu kesatuan yang ditonjolkan adalah kampanye politiknya yang menyeluruh disemua kalangan, termasuk kampanye akbar yang dilakukan oleh Joko Widodo. Pada kampanye ini semua kalangan berbondongbondong mendukung beliau dan memberikan aspresiasinya sebagai dukungan terhadap Calon Presiden yaitu Joko Widodo. Hal ini juga dibenarkan oleh key informan penelitian ini yaitu selaku anggota Tim Kemenangan Pasangan Calon Presiden Joko Widodo yang membuat postingan diakun instagram pribadi miliknya. Bahwa beliau merasa bangga menjadi bagian dari tim pendukung Joko Widodo dan mengatakan bahwa Joko Widodo sangat sopan dengan pasangan calonnya. Hal ini yang menjadi daya tarik masyarakat untuk memilih Joko Widodo. Terkadang gambaran ini memberitahukan masyarakat atau pemilih 
untuk mengenal kandidat tersebut sehingga mereka bias memilih kandidat yang bersangkutan. Hal tersebut menerangkan bahwa sosial media instagram sangat efektif dalam membentuk citra positif.

Selain itu hasil penelitian diatas membahas kampanye politik yang dilakukan oleh Joko Widodo. Dalam konteks pemilihan presiden, tentunya kandidat melakukan komunikasi agar mendapat citra yang baik sebagai pemimpin. Salah satunya citra tersebut dapat diperoleh melalui kampanye politik. Lebih lanjut, manajemen citra politik merupakan kampanye politik dalam aktivitasnya untuk membentuk citra, dengan tujuan utama mempersuasi pemegang hak suara. Pada foto dan video yang diunggah di Instagram ketika kampanye, Joko Widodo memperlihatkan bahwa tidak memiliki jarak dengan rakyat, meskipun statusnya adalah orang nomor satu di Indonesia. Pernyataan tersebut didukung dari gambar diatas yang memperlihatkan Joko Widodo saat melakukan kampanye diberbagai Kota. Hal ini menunjukan bahwa Joko Widodo memiliki sifat-sifat unggul seperti cerdas, dinamis, kuat, kreatif tetapi juga defensif di waktu yang bersamaan sehingga menciptakan dua citra sekaligus.

Hasil penelitian diatas menggambarkan bahwa media social instagram merupakan media online yang para penggunanya dapat saling berkomunikasi dan terhubung, berpartisipasi, berbagi, dan menciptakan konten dari media yang digunakan. Penggunaan media social instagram untuk membangun citra positif Joko Widodo dalam pilpres 2019 sangat berpengaruh positif. Sesuai dengan penelitian terdahulu menurut Dewi \& Janitar (2018) yang mengatakan bahwa media sosial mempunyai peran yang cukup besar dalam membangun demokrasi di Indonesia, khusunya partisipasi masyarakat dalam menyampaikan pendapat dan berekspresi. Penelitian lainnya (Ma'aruf, \& Putra 2019) menerangkan bahwa sosial media instagram sangat efektif dalam membentuk personal branding pada saat kampanye. Menurut Cindy (2019), Joko Widodo yang terbilang cukup aktif di media sosial Instagram, meski memiliki kegiatan yang sangat padat. Jokowi juga menunjukkan citra dirinya melalui setiap postingan yang diunggah di Instagram. Maka dalam membangun citra positifnya dalam pemilihan presiden 2019 Joko Widodo menggunakan media social instagram dan terbukti efektif digunakan.

Di dalam interaksi sosial, setiap individu berupaya menunjukkan image dirinya di depan orang lain. Upaya ini menggambarkan bahwa individu secara sengaja menggunakan komunikasi untuk menciptakan kesan yang diinginkan dari orang lain terhadap dirinya. Melalui media sosial semua masyarakat dapat memberikan kontribusi yang sangat terbuka dan bebas dalam perkembangan demokrasi di Indonesia. Status-status yang ada pada sosial media begitu sangat bergairah dan cepat dalam menyampaikan berbagai kritik maupun aspirasi melalui akun-akun resmi yang dimiliki oleh calon presiden atau lembaga-lembaga lainnya di Indonesia. Hal ini sesuai dengan teori new media yang mengatakan bahwa adanya kontribusi media membuat masyarakat sekarang menjadi masyarakat yang lebih terbuka. Secara umum, dapat mendiskusikan bahwa media mainstream dan dapat melayani informasi publik dengan benar, karena media tidak mampu menyajikan informasi politik yang seimbang. Oleh karena itu setiap masyarakat perlu memilah dan memilih informasi yang dapat diterima dengan baik dan benar.

Berdasarkan hasil penelitian sejak masa kampanye hingga pemilihan presiden, interaksi yang dilakukan Joko Widodo diakun instagram miliknya sering mengunggah tentang berbaurnya beliau dengan masyarakat seperti mengunggah potretnya yang sedang berinteraksi dengan driver gojek, dan interaksi yang dilakukan pendukungnya yang menyuarakan dukungannya terhadap Joko Widodo. Berdasrkan pengamatan di Instagram milik Joko Widodo, ia memposting sekitar 50 foto tentang kedekatannya dengan masyarakat dan foto tersebut mendapatkan ratusan ribu likes. Hal ini menunjukan interaksi social terjadi antara followers akun Joko Widodo serta pemilik akun Instagram lainnya sebagai penonton.

Dina Fadiyah \& Jimmy Simorangkir:

Penggunaan Media Sosial Instagram Dalam Membangun Citra Positif Presiden Joko Widodo Pada Pilpres 2019 
Pencapaian yang diinginkan yaitu untuk memenangkan pemilihan presiden 2019, agar tujuannya tercapai dengan memproleh suara yang lebih dari 50 persen. Sehingga interaksi media social instagram sangat penting dalam membangun citra. Jumlah total postingan di Instagram Joko Widodo selama kampanye terdiri dari 502 post. Ini merupakan upaya Joko Widodo dalam membangun citra dan memberikan informasi atau kampanye secara ringan dan cepat tersampaikan terhadap masyarakat luas hanya dalam satu waktu semua dapat melihat informasinya. Informasi yang diberikan Instagram, dapat menjadi media penggerak opini karena banyak pesan yang diterima publik tentang kampanye. Pembentukan citra ini hal yang sangat penting, karena presentasi diri di hadapan pemilih potensial dapat menentukan menang atau kalah dalam proses pemilihan.

Di saat yang bersamaan, ruang untuk membentuk citra diri semakin dipermudah dengan adanya perkembangan media sosial. Politisi tidak perlu lagi mengandalkan media massa konvensional. Keberadaan media sosial menjadikan setiap individu menjadi komunikator massa yang dapat melakukan konstruksi citranya masing-masing. Berdasarkan hasil penelitian diatas informan dan key informan memberikan gambaran mengenai media social, bahwa media social yang digunakan adalah instagram. Instagram sangat mudah diakses pada zaman sekarang ini, apalagi dengan modal kuota saja kita dapat mengakses informasi terutama kampanye dan berita terbaru mengenai pemilihan presiden 2019.

Joko Widodo dalam akun instagram miliknya selalu memposting berbagai kegiatannya, sehingga banyak masyarakat yang tertarik dan simpati terhadap perilakunya. Joko Widodo tidak hanya memainkan peran sebagai pemimpin sebuah negara dan calon presiden didalam Instagramnya, tetapi juga sebagai pemimpin keluarganya. Pada postingannya, Joko Widodo juga mempublikasikan tentang kemesraan dengan keluarganya yaitu dengan istrinya, Iriana Widodo yang mendampinginya saat kampanye. Hal ini dibuktikan dengan jumlah like dan followers yang banyak diakun miliknya tersebut. Hal ini sesuai dengan pendapat dari penelitian Sandra (2013) yang mengatakan media sosial seperti Instagram dapat membentuk visualisasi seseorang dengan segala aktivitasnya. Media seperti ini dapat membentuk dan membangun pendapat umum dengan cara visualisasi yang baik dan sesuai dengan pengharapan masyarakat.

Di Instagram miliknya, seluruh potretnya memperlihatkan bahwa Joko Widodo mengenakan kemeja berwarna putih yang lengannya digulung. Warna putih telah menjadi identitas bagi Joko Widodo sejak menggulung lengannya, artinya beliau siap bekerja dengan hati yang bersih untuk kebaikan masyarakat Indonesia. Hal ini sesuai dengan slogan dari Jokowi: kerja, kerja, dan kerja. Selain itu, didukung oleh pendapat dari key informan bahwa sangat bangga dapat menjadi bagian dari tim pendukung kemenangan nasional Joko Widodo yang memberikan citra atau kesan untuk menggerakan masyarakat lainnya. Citra yang baik sangat bisa menjadi faktor penentu kemenangan dalam pemilihan presiden. Namun, keberhasilan tergantung pada kemampuan dalam menjalankan tugasnya. Sebab, media social mampu mengubah citra menjadi perolehan suara adalah individu yang memiliki keahlian untuk tampil di hadapan masyarakat. Keberadaan sosial media di Indonesia memiliki posisi yang sangat penting atau sentral. Media sosial semakin nyaman digunakan oleh manusia dalam pencarian informasi. Selain itu, bermanfaat untuk menggantikan komunikasi tatap muka. Sebab, tidak mungkin untuk seorang elit politik bertemu dengan ratusan juta penduduk Indonesia. Instagram merupakan media sosial yang memperbolehkan penggunannya untuk bebas mengunggah foto maupun video. Pengguna dapat mengikuti dan diikuti akun lainnya. Dimana terdapat fitur pencarian, komentar, serta pemberian tanda suka (like) kepada unggahan diri sendiri maupun akun lain. Sehingga interaksi komunikasi penggunaan media social instagram dapat berjalan dengan mudah dan efektif digunakan dalam mencapai tujuan kemenangan pemilihan presiden 2019. 


\section{SIMPULAN}

Penggunaan media social instagram dapat membangun citra positif Joko Widodo. Hal ini dibuktikan melalui akun instagram miliknya dengan membangun kesan di hadapan audiens meliputi mengunggah potret-potret keberhasilannya sebagai kepala negara, antara lain membangun infrastruktur di berbagai tempat di Indonesia, dan mempunyai banyak like disetiap postingannya. Selain itu tampak adanya konsistensi dalam membangun citra Jokowi selama masa kampanye, dimana Joko Widodo memiliki sifat-sifat superior seperti unggul, dominan, kuat, pengelola yang baik, cerdas, dinamis, kekinian dan sifat membumi yang melekat seperti kesederhanaan atau santai.

Joko Widodo sangat terbuka dan lebih tampil ofensif di Instagram sehingga memanfaatkan Instagram pribadinya untuk kampanye politik. Sehingga lebih instagram miliknya sangat aktif di Instagram dibandingkan dengan lawan paslon presiden lainnnya. Hal itu dilakukan demi menarik perhatian masyarakat Indonesia untuk memilih Joko Widodo dalam Pilpres 2019. Interaksi komunikasi yang digunakan melalui media social Instagram dipilih karena calon presiden tidak perlu takut terhadap filter wartawan dan dapat menjangkau masyarakat lebih luas, sehingga interaksi komunikasi dalam penggunaan media social instagram dapat berjalan dengan mudah dan efektif digunakan dalam mencapai tujuan kemenangan pemilihan presiden 2019.

\section{DAFTAR PUSTAKA}

Aditya, A., Bevly, B., Haryanto, D., Yulwardian, E., Nasution, E., Rachman, F., \& Hartono, Y. (2013). Social Media Nation: 15 Inspirasi Berjejaring Sosial: Bertumbuh Besar Bersama Komunitas Online dan Sukses Berbisnis. Jakarta: Prasetiya Mulya Publishing.

Ardha, B. (2014). Social Media sebagai Media Kampanye Partai Politik 2014 di Indonesia. Jurnal Visi Komunikasi, 13(1), 105-120. http://dx.doi.org/10.22441/jvk.v13i1.383

Armstrong, G., Adam, S., Denize, S., \& Kotler, P. (2014). Principles Of Marketin. Jakarta: Erlangga.

Bungin, B. (2009). Analisis Penelitian Data Kualitatif. Jakarta: Raja Grafindo.

Cindy C. \& Sari W. P. 2019. Citra Diri Dalam Instagram Jokowi. Jurnal Koneksi 3(2): 4450. http://dx.doi.org/10.24912/kn.v3i2.6380

Dewi, R., \& Janitra, P. A. (2018). Dramaturgi Dalam Media Sosial: Second Account Di Instagram Sebagai Alter Ego. Jurnal Ilmu Komunikasi, 8(3), 340-347. https://jkms.ejournal.unri.ac.id/index.php/JKMS/article/view/5671

Efendi, A., Astuti, P. I., \& Rahayu, N. T. (2017). Analisis Pengaruh Penggunaan Media Baru Terhadap Pola Interaksi Sosial Anak di Kabupaten Sukoharjo. Jurnal Penelitian Humaniora, 18(2), 12-24. https://doi.org/10.23917/humaniora.v18i2.5188

Fairclough, N. (1992). Discourse and Text: Linguistic and Intertextual Analysis Within $\begin{array}{llll}\text { Discourse } \quad \text { Analysis. Discourse } \quad \& \quad \text { society, 3(2), } & \text { 193-217. }\end{array}$ https://doi.org/10.1177/0957926592003002004

Fauzia, A. Z., Maslihah, S., \& Ihsan, H. (2019). Pengaruh Tipe Kepribadian Terhadap SelfDisclosure Pada Dewasa Awal Pengguna Media Sosial Instagram di Kota 
Bandung. Journal of Psychological Science and Profession, 3(3), 151-160. https://doi.org/10.24198/jpsp.v3i3.23434

Firmanzah, M. P. (2007). Marketing Politik: Antara Pemahaman dan Realitas. Jakarta: Yayasan Obor Indonesia.

Kertamukti, R. (2015). Instagram dan Pembentukan Citra (Studi Kualitatif Komunikasi Visual dalam Pembentukan Personal Karakter Account Instagram @ basukibtp). Profetik: Jurnal Komunikasi, 8(1). http://ejournal.uinsuka.ac.id/isoshum/profetik/article/view/1101

Lees-Marshment, J. (2001). Political marketing and British political parties: The party's just Begun. London: Manchester University Press.

Ma'aruf, A. R. S., \& Putra, D. K. S. (2019). Efektivitas Penggunaan Media Sosial Instagram Terhadap Personal Branding Joko Widodo Pada Pemilih Pemula Pemilu 2019. Jurnal Ilmu Komunikasi Acta Diurna, 15(2), 1-18. http://dx.doi.org/10.20884/1.actadiurna.2019.15.2.2129

Ramadhan, M. G. J. 2019. Efektifitas Sosial Media Instagram @Jokowi Dalam Membentuk Personal Branding Pada Kampanye Pilpres 2019. Universitas Muhammadiyah Tangerang 2(1). http://dx.doi.org/10.31219/osf.io/arn48

Sandra, L. J. (2013). Political Branding Jokowi Selama Masa Kampanye Pemilu Gubernur DKI Jakarta 2012 di Media Sosial Twitter. Jurnal E-komunikasi: 1(2). http://publication.petra.ac.id/index.php/ilmu-komunikasi/article/view/912

Saputro, G. E., \& Haryadi, T. (2018). Edukasi Kampanye Anti Hoax melalui Komik Strip. Demandia: Jurnal Desain Komunikasi Visual, Manajemen Desain, dan Periklanan, 3(02), 238-255. https://doi.org/10.25124/demandia.v3i02.1550

Satori, D. A., \& Komariah, A. (2009). Metodologi penelitian kualitatif. Bandung: Alfabeta.

Scammell, M. (2007). Political brands and consumer citizens: The rebranding of Tony Blair. The Annals of the American Academy of Political and Social Science, 611(1), 176-192. https://www.jstor.org/stable/25097916

Schroder, Peter. 2011. Strategi Politik. Jakarta: Frierdrich-Nauman-Stiftung Fur Diefreihet.

Simangunsong, B. (2004). Negara, demokrasi, dan berpolitik yang profesional. Jakarta: Kharisma Virgo Print.

Uchjana, O. (2003). Ilmu, Teori dan Filsafat Komunikasi. Bandung: PT Citra Aditya Bakti. 